\title{
SPRAWOZDANIE Z KONFERENCJI „PO TYM, JAK LUDZIE PRZESTALI BYĆ SZCZĘŚLIWI. CZLOWIEK A MIARY CZASU I PRZESTRZENI W PRZE- SZŁOSCI", BIAŁYSTOK, 26-27 PAŹDZIERNIKA 2006 R.
}

W dniach 26-27 października 2006 r. w Instytucie Historii Uniwersytetu w Białymstoku odbyła się konferencja pt. Potym, jak ludzie przestali być szczęśliwi. Człowiek a miary czasu $i$ przestrzeni w przeszłości. Jej celem było stworzenie możliwości zaprezentowania najnowszych osiągnięć badawczych związanych z chronologią, metrologią i geografią historyczną, podsumowanie stanu badań w tych dziedzinach i stworzenie forum, na którym zostałyby przedyskutowane postulaty zgłaszane wkontekście społecznego wymiaru mierzenia czasu, przestrzeni i mierzenia w ogóle, $z$ uwzględnieniem perspektywy antropologicznej.

W czasie konferencji wygłoszono 16 referatów. Historycy $z$ Białegostoku, Siedlec, Lublina, Torunia, Zielonej Góry i Kijowa zaprezentowali badaną problematykę zarówno $z$ perspektywy tradycyjnego podejścia do nauk pomocniczych historii, jak i antropologii, historii historiografii i metodologii historii.

Do tych ostatnich należały referaty: Tomasza Mojsika (Manipulacja przestrzeniq $i$ czasem $w$ historiografii. Perspektywa narratywistyczna), Dariusza Magiera (Czasoprzestrzeń biurokracji) i Adama Drążka (Diagnostyka czasu i przestrzeni w ujęciu Wlodzimierza Lenina. Implikac je teoretyczno-polityczne).

Systemami miar i wag w ich lokalnym wymiarze zajęli się: Joanna Karczewska (Sredniowieczne miary powierzchni ziemi w Wielkopolsce i na Kujawach $w$ swietle ksiagg sqdowych), Władysław Berkowski (Rozwój systemów miar i wag na Wołyniu $w$ XVI $i$ w pierwszej polowie XVII wieku) i Witold Bobryk (Geografia miar na terenie eparchii lwowskiej w świetle wizytacji generalnej z polowy XVIII wieku).

Chronologia, nie tylko w wymiarze technicznym, była przedmiotem rozważań Janusza Łosowskiego (Zegarowy pomiar czasu $w$ dawnych miastach polskich (XVI-XVIII wiek). Problemy badawcze), a kwestie wprowadzenia 
kalendarza gregoriańskiego przez ewangelików polskich i litewskich podjęła Marzena Liedke (Kalendarz gregorianiski $w$ życiu litewskiej Jednoty ewangelicko-reformowanej $w$ XVII wieku).

Rytm życia codziennego i rocznego dawnych mieszkańców Rzeczypospolitej został zaprezentowany w referatach: Iwony Kuleszy-Woronieckiej (Rytm życia codziennego w świetle pamiętnikówz XVII $i$ XVIII wieku), Adama Kucharskiego (Czas $i$ przestrzeń $w$ staropolskich dziennikach podróży XVII wieku),Piotra Guzowskiego (Kalendarz gospodarczy i finansowy kmieci polskich na przełomie średniowiecza $i$ czasów wczesnonowożytnych) oraz Karola Łopateckiego (Rola czasu w funkcjonowaniu życia obozowego wśród wojsk koronnych $i$ litewskich $w$ XVI-XVIII wieku). Podobnymi zagadnieniami, dotyczącymi nowożytnej Anglii, zajęli się: Dorota Guzowska (Niezwykły dzień zwykłych ludzi: teoria i praktyka sabatarianizmu w siedemnastowiecznej Anglii) i Jacek Brzozowski (Zwykły dzień niezwykłego człowieka. Rozrywka i praca Samuela Pepysa).

Zagadnienia związane $z$ geografią historyczną stały się przedmiotem rozważań Przemysława Czyżewskiego (Terytorium parafii jako jednostki administracji kościelnej i panstwowej w XVIII wieku) i Stanisława Alexandrowicza (Przydatność źródet kartograficznych w badaniach nad historiq Rzeczypospolitej Obojga Narodów). Krzysztof Boroda zaś starał się zbadać kategorie metrologiczne używane przez aparat fiskalny państwa (Kmieć, tan czy profit? Co leżało u podstaw systemu podatkowego Rzeczypospolitej $w$ XVI wieku?).

Konferencja poświęcona zagadnieniom nauk pomocniczych historii okazała się bardzo potrzebna. W obliczu zmarginalizowania tej tematyki we współczesnej polskiej historiografii zwróciła uwagę na niedostatecznie opracowane i doceniane problemów z zakresu chronologii, metrologii i geografii historycznej, szczególnie eksponując aspekt antropologiczny, związany z życiem codziennym. Organizatorzy spotkania liczą, że białostocka konferencja zapoczątkuje cykl spotkań naukowych podejmujących problematykę także innych nauk pomocniczych historii.

Piotr Guzowski, Marzena Liedke 